INFLAMMATORY BOWEL DISEASE

\title{
Systemic administration of the chemokine macrophage inflammatory protein $1 \alpha$ exacerbates inflammatory bowel disease in a mouse model
}

\author{
S L-F Pender, V Chance, C V Whiting, M Buckley, M Edwards, R Pettipher, T T MacDonald
}

Gut 2005;54:1114-1120. doi: 10.1136/gut.2004.052779

See end of article for authors' affiliations

Correspondence to: Professor T T MacDonald, Centre for Infectious Disease, ICMS, Barts and the London School of Medicine and Dentistry Whitechapel, London E' 1 2AT, UK; t.t.macdonald@ qmul.ac.uk

Revised version received 10 January 2005

Accepted for publication 3 February 2005

\begin{abstract}
Introduction: Exacerbations of inflammatory bowel disease are thought to be related to concurrent infections. As infections are associated with elevated local and serum concentrations of chemokines, we have determined whether systemic administration of the CC chemokine macrophage inflammatory protein $1 \alpha($ MIP- $1 \alpha)$ exacerbates colitis in a mouse model.

Methods: Colitis was induced in Balb/c mice using trinitrobenzene sulfonic acid (TNBS). Starting four days later, animals received daily intraperitoneal injections of recombinant MIP-1 $\alpha$. On day 7 , mice were killed and pieces of colon taken for immunohistology and polymerase chain reaction analysis. The direct effects of MIP-1 $\alpha$ on mucosal T cells and fibroblasts in vitro were also investigated.

Results: Systemic administration of MIP-1 $\alpha$ markedly enhanced colitis with mice developing large transmural ulcers filled with granulation tissue. Treatment resulted in increased numbers of CD4 cells infiltrating the colonic lamina propria, increased interferon $\gamma$ (IFN- $\gamma$ ) levels, and increased transcripts for tumour necrosis factor $\alpha$ (TNF- $\alpha$ ) and matrix metalloproteinase 3 (MMP3). Isolated lamina propria lymphocytes from mice with TNBS colitis contained increased numbers of IFN- $\gamma$ and TNF- $\alpha$ transcripts when stimulated with MIP- $1 \alpha$ in vitro. Colonic lamina propria fibroblasts also responded to MIP- $1 \alpha$ with increased proliferation and decreased collagen 1 synthesis but fibroblast proliferation was not seen in vivo.

Conclusions: These experiments show that increasing serum concentrations of a chemokine, MIP- $1 \alpha$, exacerbates immune mediated colitis. The effect seems to be due to the ability of MIP- $1 \alpha$ to boost Th1 responses in the gut wall. Our findings also suggest a potential pathway by which peripheral infections can exacerbate inflammatory bowel disease.
\end{abstract}

W hile there are now many and varied strategies to induce remission in patients with inflammatory bowel disease (IBD), the high relapse rates continue to be problematic. There are very few clues as to why some patients remain disease free for pronged periods while others relapse rapidly. Crohn's patients, whose mucosal biopsies secrete high levels of tumour necrosis factor $\alpha$ (TNF- $\alpha$ ), relapse faster than those who secrete low levels of TNF- $\alpha$, ${ }^{1}$ but this may merely reflect the fact that the former were not really in remission and that definitions of clinical remission are insensitive. ${ }^{2-4}$ Indeed, a classic study by Modigliani et al showed that the majority of patients in clinical remission after treatment with prednisolone had lesions visible at endoscopy. ${ }^{5}$

There is also a large body of largely anecdotal evidence to suggest that extraintestinal events may trigger relapse in IBD. Acute viral enteritis may trigger relapse symptoms ${ }^{6}$ and epidemiological and microbiological studies suggest that infections with gut pathogens trigger relapse (reviewed by Stallmach and Carstens ${ }^{7}$ ). Gut infections however cannot be responsible for relapse in the majority of cases because these are relatively rare in developed countries, especially in adults. On the other hand, respiratory tract infections are common in adults and children in the developed world and respiratory infections have been shown to be associated with relapse in paediatric IBD. ${ }^{8}$

Viral infection of respiratory tract epithelial cells in vitro and during in vivo infection leads to the production of a large number of chemokines such as RANTES, macrophage inflammatory protein $1 \alpha($ MIP- $1 \alpha)$, monocyte chemoattractant protein 1, and interleukin (IL) $-8,{ }^{9-13}$ the function of which is to attract inflammatory cells from the blood into the tissues. Consequently, elevated concentrations of these chemokines are found in serum, and nasopharyngeal and tracheal secretions of children with respiratory tract infections. $^{9-12}$

Chemokines however have a much broader role than merely attracting leucocytes into tissues. There is now a large body of evidence to show that the binding of a chemokine to its receptor (a $G$ protein coupled receptor) can modulate leucocyte activity by activating intracellular signal transduction pathways. ${ }^{14-17}$

In this study, we have therefore attempted to model the effects of elevated concentrations of chemokines as a result of infection by direct systemic injection of recombinant protein into mice with trinitrobenzene sulfonic acid (TNBS) colitis. The chemokine we chose to investigate was MIP-1 $\alpha$ (CCL3) as it is well established as being present at elevated concentrations in airway infection..$^{9-12}$ MIP- $1 \alpha$ is a C-C chemokine with three cell surface receptors, CCR1, CCR3, and CCR5. ${ }^{18}$ It is made by many different cell types and in vivo and in vitro, it is a chemoattractant for natural killer cells, monocytes, neutrophils, T cells, and B cells. ${ }^{18-20}$ Our results indicate that MIP- $1 \alpha$ exacerbates colitis, probably by

\footnotetext{
Abbreviations: MIP- $1 \alpha$, macrophage inflammatory protein $1 \alpha$; TNBS, trinitrobenzene sulfonic acid; TNF- $\alpha$, tumour necrosis factor $\alpha$; MMP3, matrix metalloproteinase 3; IBD, inflammatory bowel disease; IL, interleukin; PCR, polymerase chain reaction; LPL, lamina propria lymphocytes; FCS, fetal calf serum; TGF- $\beta$, transforming growth factor $\beta$; PBS, phosphate buffered saline; PBT, PBS/Tween 20; BSA, bovine serum albumin
} 
directly augmenting the function of activated Thl cells in the gut wall.

\section{MATERIALS AND METHODS Induction of colitis}

TNBS (Fluka, Gillingham, UK) was prepared in a 50\% ethanol solution diluted to give a final concentration of $2 \mathrm{mg}$ TNBS in $75 \mu \mathrm{l}$ total volume. Adult female Balb/c mice weighing more than $20 \mathrm{~g}$ were lightly anaesthetised using $200 \mu \mathrm{l}$ of a $1 / 10$ aqueous dilution of Hypnorm (Janssen-Cilag, High Wycombe, UK). Colitis was induced by intrarectal administration of $75 \mu \mathrm{l}$ of the TNBS solution using a plastic catheter. Control mice received $50 \%$ aqueous ethanol only. Mice were checked daily with respect to general condition and body weight. On days 4-6, mice were injected with $0.2 \mu \mathrm{g}, 2$, or $20 \mu \mathrm{g}$ recombinant murine MIP- $1 \alpha$ in PBS (Oxagen Ltd). Controls received phosphate buffered saline (PBS) alone. Animals were killed on day 7. This work was carried out with both institutional and Home Office approval.

\section{Immunohistochemistry}

Mice were killed and the last $4 \mathrm{~cm}$ of the distal colon dissected out. The tissue was opened, washed, and weighed. A small piece was taken for polymerase chain reaction (PCR) and the rest was dissected open, rinsed in PBS, and tightly rolled along the longitudinal axis, then immediately snap frozen in liquid nitrogen and stored at $-80^{\circ} \mathrm{C}$. Three step avidin-peroxidase staining was then performed on $5 \mu \mathrm{M}$ frozen sections, as described previously, ${ }^{21}$ using monoclonal antibodies YTS191 (anti-CD4), Ki67, and HLA-DR (Dako Ltd, Cambridge, UK). Biotin conjugated rabbit anti-rat IgG and goat antirabbit (Dako) were used at $1 / 50$ dilution in Tris buffered saline ( $\mathrm{pH} 7.6)$ containing $4 \%(\mathrm{v} / \mathrm{v})$ normal mouse serum (Harlan Seralab, Oxon, UK). Peroxidase activity was detected with 3.3"'-diaminobenzidine tetrahydrochloride (Sigma, Poole, U.K.) in $0.5 \mathrm{mg} / \mathrm{ml}$ Tris $\mathrm{HCl}$ (pH 7.6), containing $0.01 \% \mathrm{H}_{2} \mathrm{O}_{2}$ (Sigma). The density of positive cells in the lamina propria was determined by image analysis (Zeiss, UK).

\section{RNA extraction and quantitative RT-PCR}

Total cellular RNA was isolated from frozen colonic tissues by homogenisation of the tissue in TRIzol (Invitrogen, Paisley, UK) followed by chloroform extraction and isopropanol precipitation. Total RNA was measured at $260 \mathrm{~nm}$ by spectrophotometric analysis (Beckman Coulter, Buckinghamshire, UK). Cytokine encoding plasmid (pCMQ2), kindly provided by MF Kagnoff (Department of Medicine, University of California, San Diego, California, USA), was used for quantitative competitive PCR for TNF- $\alpha$ transcripts, as described previously. ${ }^{21}$ To quantify mouse matrix metalloproteinase 3 (MMP3) mRNA levels, we constructed a plasmid that encoded a standard RNA. ${ }^{22}$

\section{Interferon $\gamma($ IFN- $\gamma$ ) measurements}

Mice were given TNBS and on days 4-6 they were given $2 \mu \mathrm{g}$ MIP- $1 \alpha$. On day 7 , the animals were killed and a segment of distal colon was dissected out and snap frozen in liquid nitrogen. Samples were homogenised in ice cold extraction buffer ( $50 \mathrm{mM}$ Tris $\mathrm{HCl}$ ( $\mathrm{pH} 7.4$ ), $10 \mathrm{mM} \mathrm{CaCl}_{2}, 0.05 \%$ Brij $35,0.25 \%$ Triton $\mathrm{X}-100$ ) at maximum speed for 30 seconds using IKA tissue homogeniser (Fischer, Loughborough, UK). Homogenates were centrifuged at $13000 \mathrm{rpm}$ for 10 minutes at $4{ }^{\circ} \mathrm{C}$ and the supernatants were removed and assayed for protein concentration (Bio-Rad, Hertfordshire, UK). IFN- $\gamma$ in the supernatants was then measured using a commercial ELISA (R\&D Systems, Abingdon, Oxon, UK) with a lower limit of sensitivity of $2 \mathrm{pg} / \mathrm{ml}$.

\section{In vitro stimulation of lamina propria lymphocytes} (LPL)

Four days after TNBS or ethanol, mice were killed and LPL isolated from the colon by first removing the epithelium with EDTA (confirmed by histology) and collagenase digestion, as described previously. ${ }^{23}$ The same frequency of $\mathrm{T}$ cells (approximately $30 \%$ ) was seen in cells isolated from ethanol controls and mice with TNBS colitis but the total cell yield was much higher in the latter group. One million cells were cultured in $1 \mathrm{ml}$ RPMI 1640 with $10 \%$ heat inactivated fetal calf serum and antibiotics for 48 hours with and without addition of MIP- $1 \alpha$. At the end of the culture period, cells were harvested from 3 wells/group, pooled, and RNA extracted for PCR. Supernatants were also collected and stored at $-70^{\circ} \mathrm{C}$ and IFN- $\gamma$ measured by ELISA.

\section{Fibroblast cell culture}

Colons were taken from three six week old week old Balb/c mice, cut open, and vigorously washed in cold PBS. The epithelium and mucus were scraped off with a scalpel blade and discarded. The remaining tissue was minced with two scalpel blades in serum free RPMI culture medium containing antibiotics (penicillin/streptomycin 200 units $/ 200 \mu \mathrm{g} / \mathrm{ml}$, gentamycin $100 \mu \mathrm{g} / \mathrm{ml}$, and amphotericin B $0.25 \mu \mathrm{g} / \mathrm{ml}$ ) and HEPES $(20 \mathrm{mM})$. Pieces were washed with two changes of medium. Six well plates were seeded with aliquots of the tissue in $1 \mathrm{ml} \alpha$-MEM containing antibiotics, ribonucleosides, and $10 \%$ fetal calf serum (FCS) and cultured in a humidified $\mathrm{CO}_{2}$ incubator. Half the media was replaced after four days and by day 6, out-growing fibroblasts were observed. Cells were allowed to grow in six well plates with weekly media changes until about day 21 when cells were removed with trypsin-EDTA and placed in $25 \mathrm{~cm}^{2}$ flasks. Thereafter, cells were trypsinised when confluent and flasks reseeded at 100 cells $/ \mathrm{mm}^{2}$.

Cells were grown up to at least passage 8 before there were enough to use in experiments and produced type I and IV collagens, laminin, and expressed smooth muscle cell actin, vimentin, and TGF- $\beta$ receptors I and II (not shown).

All culture media and supplements were from Invitrogen (Glasgow, UK).

ELISA for matrix proteins and cell proliferation assay A method was developed to assay deoxycholate insoluble type I collagen produced by fibroblasts grown in 96 well tissue culture plates. ${ }^{24}$ Cells (passage 10-15) were grown in flasks until just confluent, treated with trypsin-EDTA, washed once in serum containing medium, and then plated

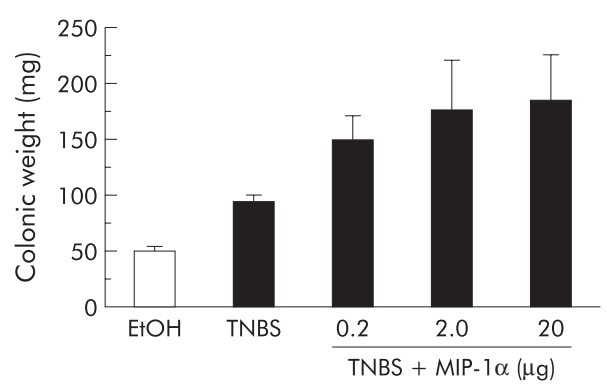

Figure 1 Effect of injection of graded doses of macrophage inflammatory protein $1 \alpha($ MIP-1 $1 \alpha)$ on colonic weight in mice with trinitrobenzene sulfonic acid (TNBS) colitis. Mice received ethanol (E†H) or TNBS and on days 4, 5, and 6 TNBS treated mice were injected with $0.2,2.0$, or $20 \mu \mathrm{g}$ MIP- $1 \alpha$. There were five mice per group and the experiment was repeated twice with the same results. All mice receiving MIP-1 $\alpha$ had significantly greater colon weights than mice receiving TNBS and vehicle alone $(p<0.05)$. 

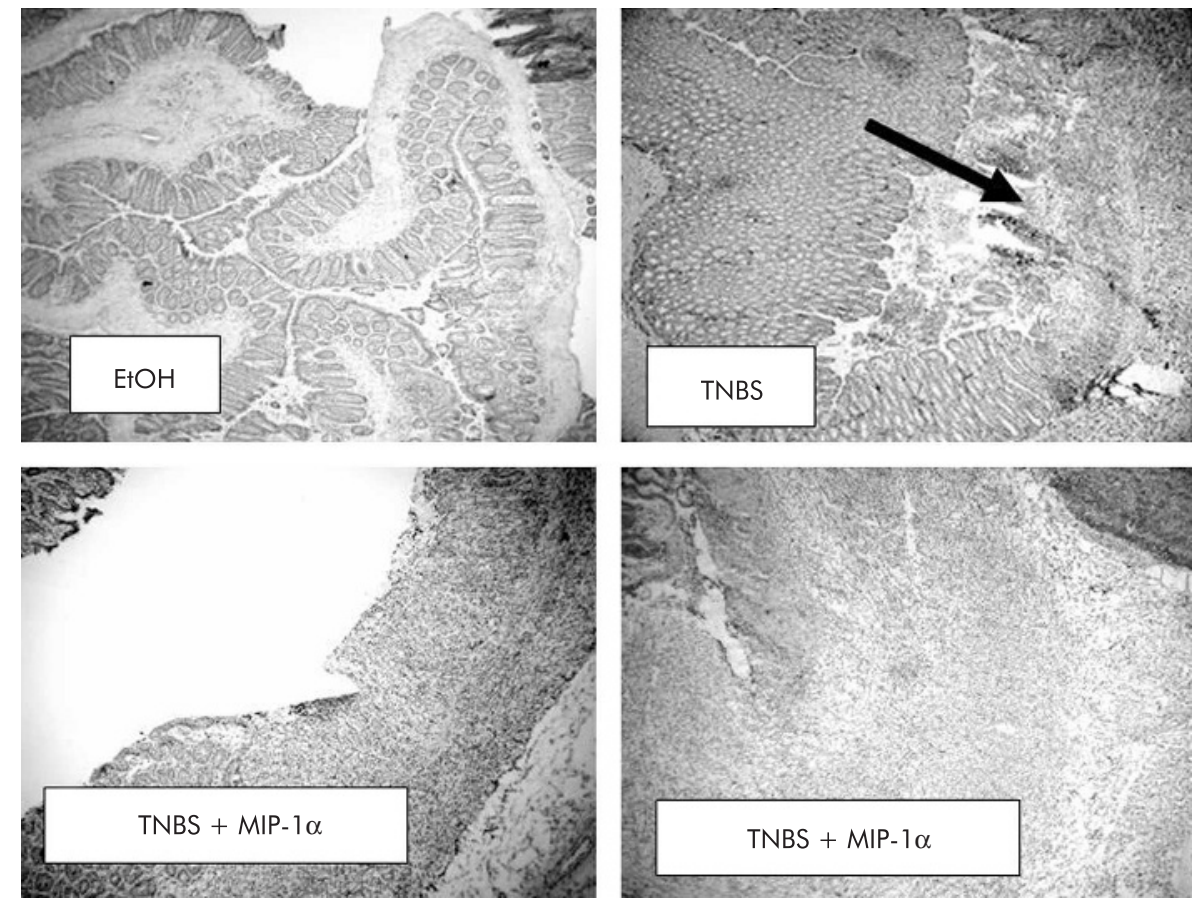

Figure 2 Histological analysis of tissues from ethanol (E†OH) controls, mice given trinitrobenzene sulfonic acid (TNBS), and mice given TNBS and macrophage inflammatory protein $1 \alpha$ (MIP-1 $1 \alpha$ ). These preparations show the thin colonic mucosa in ethanol controls. In mice given TNBS and vehicle, the mucosa is thickened and areas of ulcerations are seen (arrow). In the two examples from different animals given TNBS and $2 \mu \mathrm{g}$ MIP-1 $\alpha$, large ulcers filled with granulation tissue are all that remains of the mucosa. Haematoxylin-eosin, original magnification $\times 100$.

at 2000 cells per well. Cells were allowed to adhere for five hours at $37^{\circ} \mathrm{C}$ before gently washing three times with serum free medium. Cells were starved overnight in $50 \mu \mathrm{l}$ of $\alpha$-MEM containing $0.5 \%$ FCS (starvation medium) and then this medium was replaced with $50 \mu \mathrm{l}$ starvation medium containing MIP- $1 \alpha$ ( $1-1000 \mathrm{pg} / \mathrm{ml}), \mathrm{TGF}-\beta$ ( $1000 \mathrm{pg} / \mathrm{ml}$; R\&D), or $10 \%$ FCS as positive control (six replicates per treatment). Incubations were stopped at day 0 (after overnight starvation) and four days of culture by washing three times in PBS and air drying for two hours. Duplicate wells on each plate were left cell free and while cells were air drying, a standard curve was prepared for mouse type I collagen (kind gift from Mr T Simms, Southmead Hospital, Bristol, UK). Type I collagen standard ( $250 \mathrm{ng}$ in $10 \mu \mathrm{l} 0.05 \mathrm{M} \mathrm{HCl}$ ) was added to the first well and then serial dilutions (1:3) were made thereafter with a final volume ( $10 \mu \mathrm{l})$ remaining in the well. Plates were vortexed gently to distribute the matrix standards and then allowed to air dry for two hours. Cells were permeabilised with PBS containing sodium deoxycholate $(0.1 \%)$ and EDTA $(2 \mathrm{mM})$ for 10 minutes, washed three times in PBS/Tween $20(0.05 \%)(\mathrm{PBT})$, and then all wells were blocked with $1 \%$ BSA in PBT $(100 \mu \mathrm{l})$ for one hour. After one wash in PBT, 1:4000 rabbit anti-type I collagen $(50 \mu \mathrm{l})$ (Novotec, Paris, France) was added in PBT/BSA ( $1 \%$ ). Plates were incubated for one hour and washed four times in PBT before incubation with biotinylated donkey antirabbit antibody (1:25000; Stratech Scientific Ltd, Soham, Cambridge, UK). StreptABComplexes were prepared as per the manufacturer's instructions and then used in the ELISA at 1:50 dilution. Trimethyl benzidene in pH 5.0 citrate buffer $(100 \mu \mathrm{l})$ was used as substrate and incubated for 30 minutes. The reaction was stopped with $2 \mathrm{M} \mathrm{H}_{2} \mathrm{SO}_{4}(25 \mu \mathrm{l})$ and plates were read within 30 minutes at $450 \mathrm{~nm}$. On a separate plate, parallel sets of wells were prepared for cell counting (six replicates). Plates were incubated identically and then cells were washed and air dried as above. Cells were fixed with
$100 \%$ methanol for 10 minutes before staining with filtered Harris's haematoxylin for 10 minutes, followed by a tap water wash and air drying. Plates were inverted and cells counted using the $2.5 \times$ objective. The number of cells per field was counted manually and results are expressed as the mean (SEM) of the average number of cells per well calculated from six replicates. Type I collagen results are expressed as pg collagen/100 cells. As data are derived from independent wells, no standard error can be calculated

\section{Statistical analysis}

The significance of differences between means was determined using the paired $t$ test and the Mann-Whitney $\mathrm{U}$ test. A $p$ value of $<0.05$ was considered as significant.

\section{RESULTS \\ Systemic administration of MIP-1 $\alpha$ exacerbates the lesions in TNBS colitis}

In the first experiments, Balb/c mice with TNBS colitis were injected with MIP- $1 \alpha(0.2,2.0$, or $20 \mu \mathrm{g} /$ mouse $)$ on days 4,5 , and 6 and killed on day 7. At necropsy, the most striking feature was the very large size and weight of the distal colon in MIP- $1 \alpha$ treated mice, which was dependent on the amount of MIP- $1 \alpha$ injected (fig 1 ). The colon was markedly thickened and adherent to adjacent loops of small bowel and the abdominal wall. Histological analysis of the tissues (fig 2) showed that ethanol controls had essentially normal colonic structure. Mice given TNBS had a thickened mucosa, enlarged colonic lymphoid follicles, and the occasional small ulcer. However, animals given MIP- $1 \alpha$ showed massive areas of ulceration containing granulation tissue. Adjacent intact mucosa was grossly distorted and showed large lymphoid follicles. Ethanol controls given the full dose range of MIP- $1 \alpha$ or normal mice given MIP- $1 \alpha$ showed no change in colon weight (negative data, not shown). 

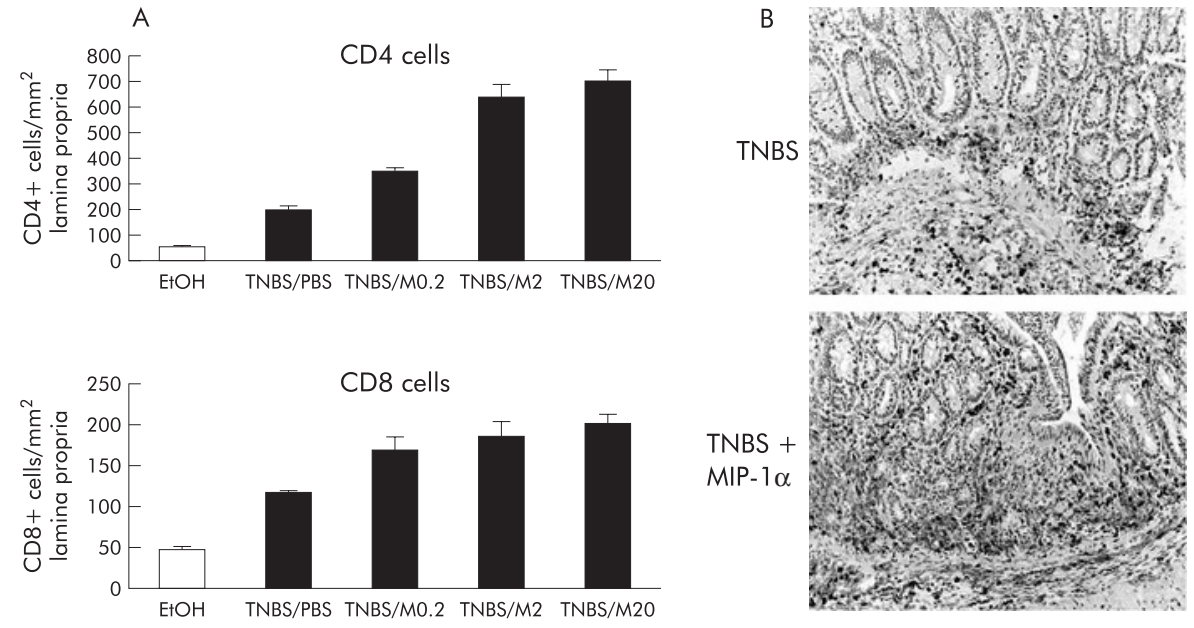

\section{C}

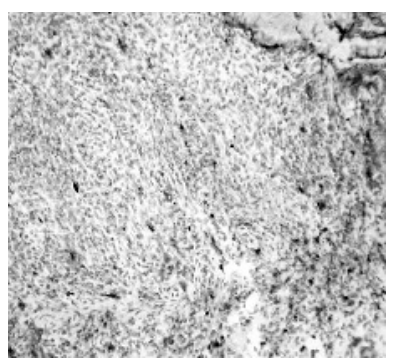

Figure 3 (A) Macrophage inflammatory protein $1 \alpha(\mathrm{MIP}-1 \alpha)$ increases the number of CD4 and CD8 cells in intact mucosa of animals given trinitrobenzene sulfonic acid (TNBS) and MIP- $1 \alpha$. Mice received ethanol (EłOH) or TNBS, and on days 4, 5, and 6 TNBS treated mice were injected with 0.2 (M0.2), 2.0 (M2), or $20 \mu \mathrm{g}$ (M20) of MIP- $1 \alpha$. There were five mice per group and the experiment was repeated twice with the same results. All mice receiving MIP- $1 \alpha$ had significantly greater numbers of CD4 and CD8 cells than mice receiving TNBS and vehicle alone $(p<0.05)$. (B) Illustration of the increase in T cells in the colon of mice given TNBS and $2 \mu \mathrm{g} \mathrm{MIP-1} \alpha$. Immunoperoxidase with anti-CD4, original magnification $\times 200$. (C) Illustration of the absence of inflammatory cells from the ulcers induced by TNBS and MIP- $1 \alpha$. Towards the left of the image is granulation tissue which almost completely lacks cells expressing MHC class II (macrophages). The right of the panel shows deeper layers of the gut wall where positive cells can be seen. Immunoperoxidase with anti-MHC class II, original magnification $\times 200$.

\section{Systemic administration of MIP- $1 \alpha$ increases inflammatory cells, cytokines, and MMPs in TNBS colitis}

Immunohistology for $\mathrm{T}$ cell and macrophage markers was used to study the lesions in TNBS and TNBS mice given MIP- $1 \alpha$. The areas containing large ulcers showed granulation tissue containing virtually no $\mathrm{T}$ cells or macrophages (fig 3C). However, these were abundant in the deeper submucosa. Adjacent regions of intact mucosa in animals treated with MIP- $1 \alpha$ showed greater numbers of CD4 cells than TNBS controls (fig 3A, B). IFN- $\gamma$ was also measured in tissue homogenates. Ethanol controls had a mean of 47 (1) $\mathrm{pg} / 200 \mu \mathrm{g}$ colonic protein $(\mathrm{n}=5)$. In mice with TNBS colitis given vehicle alone, this increased to $62(6.9) / 200 \mu \mathrm{g}$ colonic protein $(n=5$; significantly greater than the ethanol control, $\mathrm{p}<0.004)$. Mice given TNBS and MIP- $1 \alpha$ had even greater levels of IFN- $\gamma(78$ (10.7) pg/200 $\mu$ g protein; $\mathrm{n}=5$ ), which was significantly greater than TNBS mice given vehicle control $(\mathrm{p}<0.05)$.

TNF- $\alpha$ transcripts were also measured and these were increased in mice with TNBS colitis compared with ethanol controls. However, in mice treated with MIP-1 $\alpha$, even higher levels were seen (fig 4).

Finally, we also measured MMP3 transcripts as there is good evidence that it is an important end stage mediator of ulceration in the gut. These were increased in mice with TNBS colitis and further increased in mice given MIP-l $\alpha$ (fig 4).

\section{Effects of MIP-1 $1 \alpha$ on mucosal T cells}

It has already been demonstrated that MIP- $1 \alpha$ can signal to $T$ cells and increase Thl activity. ${ }^{25}$ We therefore gave mice TNBS or ethanol and four days later isolated colonic LPLs. Cells were then stimulated with low doses of MIP-1 $\alpha$ overnight and TNF- $\alpha$ and IFN- $\gamma$ transcripts measured. As expected, there were higher numbers of transcripts for both cytokines in cells from mice with TNBS colitis than cells taken from ethanol controls. Remarkably however, MIP-l $\alpha$ markedly increased Thl cytokines in cells from TNBS at a very low dose, although at a higher dose an effect was seen
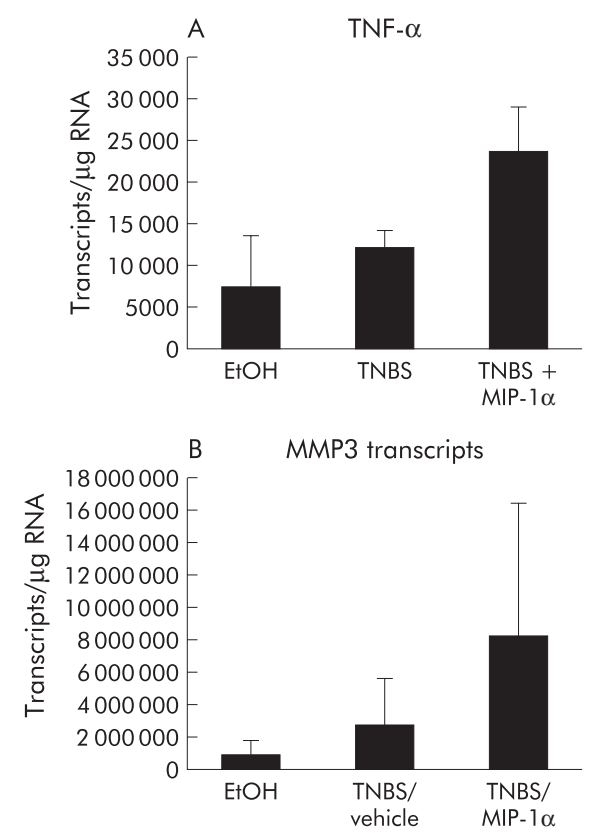

Figure 4 Macrophage inflammatory protein $1 \alpha($ MIP- $1 \alpha)$ treatment increases tumour necrosis factor $\alpha$ (TNF- $\alpha$ ) transcripts (A) and matrix metalloproteinase 3 (MMP3) transcripts (B) when given to mice with trinitrobenzene sulfonic acid (TNBS) colitis. Mice received ethanol (E†OH) or TNBS, and on days 4, 5 and 6 TNBS treated mice were injected with $2.0 \mu \mathrm{g}$ of MIP-1 $\alpha$. There were five mice per group and the experiment was repeated once with the same results. All mice receiving MIP- $1 \alpha$ had significantly greater numbers of TNF- $\alpha$ and MMP3

transcripts than mice receiving TNBS and vehicle alone $(p<0.05)$. 

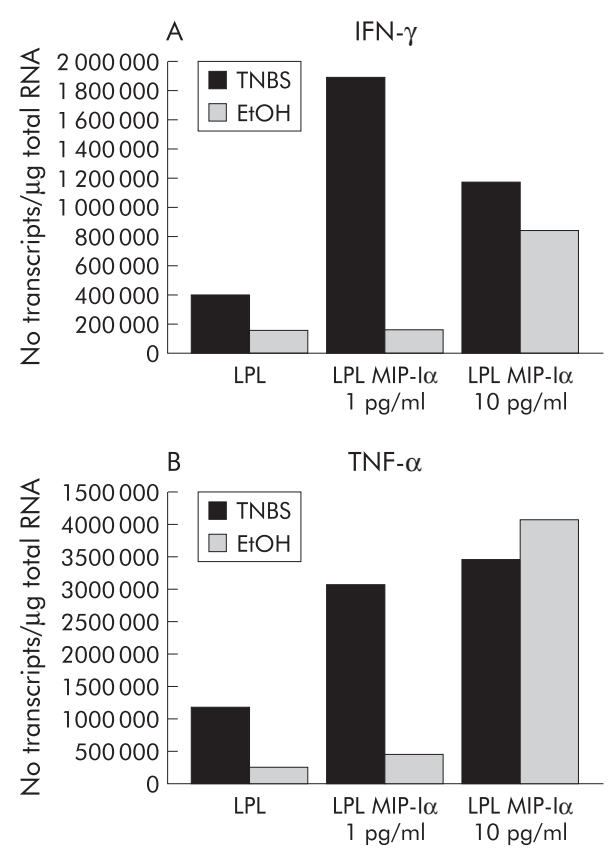

Figure 5 Macrophage inflammatory protein $1 \alpha($ MIP- $1 \alpha)$ enhances cytokine secretion by colonic lamina propria lymphocytes (LPL) from mice with trinitrobenzene sulfonic acid (TNBS) colitis. LPL from mice with TNBS colitis (day 4) or ethanol (E†OH) controls were cultured with MIP- $1 \propto$ for 48 hours and RNA transcripts measured. In control cultures, LPL from mice with TNBS colitis made more TNF- $\alpha$ and interferon $\gamma$ (IFN- $\gamma$ ) transcripts than LPL from mice given ethanol. Addition of MIP- $1 \alpha$ however markedly increased transcripts, especially in cells from mice with TNBS colitis. No statistics are shown because the data were obtained from three pooled wells/group to give enough RNA to measure for quantitative reverse transcription-polymerase chain reaction. However, the experiment was done twice with the same results.

on both ethanol and TNBS mice derived lymphocytes (fig 5). This result was also confirmed by measuring IFN $-\gamma$ protein. Unstimulated supernatants of mucosal mononuclear cells produced $36 \mathrm{pg} / \mathrm{ml}$ IFN $-\gamma$, which did not increase when MIP- $1 \alpha$ wad added. Unsurprisingly, supernatants from mice with TNBS colitis produced more IFN- $\gamma(172 \mathrm{pg} / \mathrm{ml})$ than ethanol controls, which increased even further when cells were costimulated with $1 \mathrm{pg} / \mathrm{ml}$ MIP- $1 \alpha$ to $214 \mathrm{pg} / \mathrm{ml}$.

Several experiments were also carried out to determine if MIP- $1 \alpha$ was mitogenic for either normal colonic LPL or LPL from mice with TNBS colitis. While ConA induced a weak proliferative response, MIP- $1 \alpha$ had only a very modest response on proliferation (not shown.).

\section{Effects of MIP-1 1 on gut fibroblasts}

CCR5 is expressed on fibroblasts ${ }^{26}$ and so we reasoned that a massive expansion of fibroblasts might contribute to the

Table 1 Macrophage inflammatory protein $1 \alpha($ MIP- $1 \alpha)$ induces gut fibroblast proliferation and reduces collagen I production

\begin{tabular}{lll}
\hline MIP- $1 \alpha(\mathrm{pg} / \mathrm{ml})$ & Cells $/$ well & Collagen/100 cells \\
\hline 0 & $985(56)$ & 1953 \\
1 & $1117(199)^{* *}$ & 1750 \\
10 & $1446(165)^{* * *}$ & 1418 \\
TGF- $\beta 1(1 \mathrm{ng} / \mathrm{ml})$ & $1657(288)^{* * *}$ & 1556 \\
\hline
\end{tabular}

Cell number results are shown from an average of six wells, each seeded with 1000 cells. Collagen values are shown as a single point because wells were pooled to give enough collagen to measure. ${ }^{* * *} \mathrm{p}<0.0001$. large ulcers in MIP- $1 \alpha$ treated mice. We therefore determined if MIP- $1 \alpha$ was mitogenic for fibroblasts (table 1 ). Again, at very low doses, MIP- $1 \alpha$ significantly increased fibroblast numbers and decreased collagen synthesis. However, when we used Ki67 to determine if fibroblasts were proliferating in the ulcers, there was no evidence of any cell division, although extensive proliferation of epithelial cells at the ulcer edges were seen (fig 6). It was also noticeable that in mice with TNBS colitis, large numbers of dividing cells were also seen in the muscle layers.

\section{DISCUSSION}

We have shown here that systemic administration of MIP- $1 \alpha$ markedly worsened experimental IBD in mice. The effect was dose dependent and appeared to be due to the ability of MIP- $1 \alpha$ to boost T cell responses in the gut wall. Enhanced T cell activity results in increased local levels of IFN- $\gamma$ and TNF- $\alpha$ which then probably increases MMP production by lamina propria fibroblasts, leading to extensive mucosal degradation.

MIP- $l \alpha$ is produced by many different cell types but particularly by activated macrophages. When produced at a
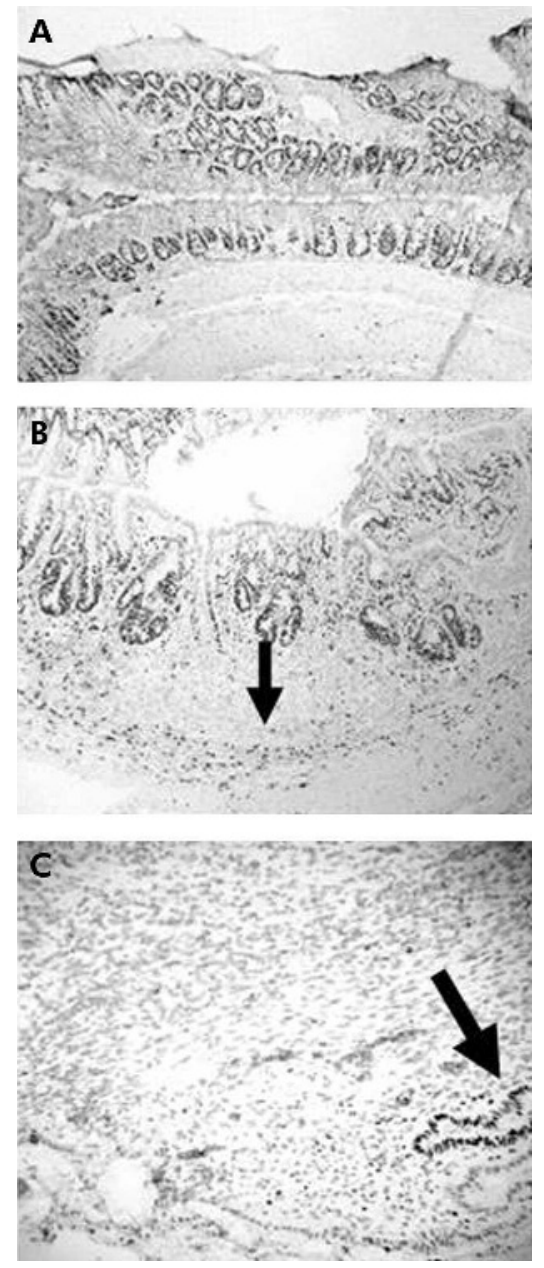

Figure 6 Ulcer beds do not contain proliferating cells, as evidenced by Ki67 staining. (A) Ki67 staining of an ethanol control is shown and staining is restricted to the base of the crypts. (B) In mice with trinitrobenzene sulfonic acid (TNBS) colitis, there is crypt lengthening and an increase in the number of Ki67+ cells. Proliferating cells are also obvious in the muscle layer (arrow). (C) In ulcer beds of mice given TNBS and macrophage inflammatory protein $1 \alpha$ (MIP-1 $1 \alpha$ ), proliferating epithelial cells are obvious at the edge of the ulcer (arrowed) but Ki67+ cells are virtually absent from the ulcer bed itself. Immunoperoxidase with Ki67, original magnification $\times 100$. 
site of infection or inflammation, it acts as a chemotactic agent which attracts lymphocytes, neutrophils, and monocytes into the tissues. However, it also leaks into the circulation and it can be detected in the serum of normal individuals at very low levels, and at increased levels in patients with infections. ${ }^{27-30}$ Systemic effects include inhibition of proliferation of haematopoietic stem cells, ${ }^{31}$ and a non-aggregating variant of MIP- $1 \alpha$ has been tested in patients for its ability to protect stem cells during chemotherapy. ${ }^{32}$ It also mobilises dendritic cell precursors and haematopoietic stem cells into the circulation. ${ }^{33}{ }^{34}$

We chose three doses of MIP-1 $\alpha$ : 10, 100, and $1000 \mu \mathrm{g} / \mathrm{kg}$. These doses are in the range shown by others for in vivo activity in mice..$^{35}$ In addition, in humans, subcutaneous administration of a bolus at $100 \mu \mathrm{g} / \mathrm{kg}$ leads to peak plasma levels of approximately $1000 \mathrm{pg} / \mathrm{ml}$ between four and six hours later. ${ }^{32}$ At a lower dose of $30 \mu \mathrm{g} / \mathrm{kg}$, peak plasma levels are approximately $500 \mathrm{pg} / \mathrm{ml}$. It is rather difficult to determine if these values correspond to levels found in the circulation of patients. In patients with a non-defined local inflammatory disease, plasma concentrations of MIP- $1 \alpha$ have a mean value of $25 \mathrm{pg} / \mathrm{ml}$, with some patients showing up to twice that level. ${ }^{27}{ }^{30}$ However, there is not a great deal of information on plasma MIP- $1 \alpha$ in different infectious and inflammatory conditions.

In mice, MIP- $1 \alpha$ signals to cells through three $G$ protein coupled receptors, CCR1, CCR3, and CCR5. ${ }^{18}$ It is not entirely clear if $\mathrm{T}$ cells in either normal or inflamed mouse colon express these receptors, although based on the knowledge that CCR5 transcripts are high in the transfer model of colitis, that CCR5 is expressed at high levels on Thl cells, and TNBS colitis is a Thl model, it is highly likely that this is the case. ${ }^{18} 36$ The therapeutic effects of MET/RANTES which blocks CCR5 signalling in rat TNBS colitis also supports the notion that $\mathrm{T}$ cells in the gut in colitis are CCR5.$+^{37}$ Likewise, CCR5 null mice are somewhat protected from DSS colitis. ${ }^{38}$

In the context of the present study however, we would suggest that exacerbation of colitis by systemic administration of MIP- $1 \alpha$ is largely due to its direct effects on T cells. While we cannot exclude other cell types, signalling through CCR5 does not appear to increase neutrophil activity and effects on macrophage function, while demonstrable, are rather modest. ${ }^{13} 3940$ We were able to show that cells taken from the colon of mice with TNBS colitis rapidly increased IFN- $\gamma$ and TNF- $\alpha$ transcripts when stimulated with MIP- $1 \alpha$ in culture. MIP- $1 \alpha$ co-stimulates human $\mathrm{T}$ cells activated with anti-CD3, increasing proliferation, and IL-2 production. ${ }^{41}$ Using T cells transgenic for an ovalbumin specific TcR, Karpus et al showed that MIP- $1 \alpha$ preferentially induced IFN- $\gamma$ production. ${ }^{25}$ Mice given ovalbumin and MIP- $1 \alpha$ by the nasal route also showed increased Thl responses in the spleen and Peyer's patches. ${ }^{42}$ The molecular basis for the costimulatory activity of MIP- $1 \alpha$ has also been demonstrated. When added to human T cell lines, MIP- $1 \alpha$ activates STATl and STAT3. ${ }^{43}$ One possible mechanistic link would be through the Thl specific transcription factor t-bet, which is activated via STAT1 signalling. ${ }^{44}$ STAT- 1 signalling also markedly enhances anti-CD3 driven Thl activation in human lamina propria $\mathrm{T}$ cells. ${ }^{45}$ Signalling though CCR5 on T cells also activates the tyrosine phosphatase SHP1, SHP2, and the Src related kinase Syk. ${ }^{46}$ These are intimately involved in $\mathrm{T}$ cell receptor signalling and their activation through CCR5 as well as through the TcR will enhance T cell cytokine production.

While we feel that the data from the literature as well as many of the studies reported here are consistent with the effects of MIP- $1 \alpha$ on TNBS colitis being through T cells, given the widespread cellular distribution of MIP- $1 \alpha$ receptors, we cannot rule out a role for other cell types. Our original hypothesis to explain these results was that MIP- $1 \alpha$ caused a massive proliferation of fibroblasts in ulcer beds, and indeed MIP- $1 \alpha$ was shown to be mitogenic for colonic fibroblasts, albeit at a rather modest level. However, when we used Ki67 to look at proliferation in ulcer beds, there was essentially no staining, which effectively negates this hypothesis.

While these studies are in a mouse model, they have some implications for IBD, especially Crohn's disease. MIP- $1 \alpha$ immunoreactivity is increased in IBD..$^{48}$ and so locally produced MIP- $1 \alpha$ could ligate CCR 5 on T cells and boost local $\mathrm{T}$ cell responses, as well as function as a chemotactic agent to draw inflammatory cells into the colon wall. Very recently it has also been shown that MIP-l $\alpha$ is increased in the colon of rats with TNBS colitis, and that a blocking antibody reduces neutrophil infiltrate. ${ }^{49}$ At the same time, the major implication of this work is that peripheral infections, by increasing plasma chemokines, may reactivate gut inflammation. This work therefore puts forward a mechanistic basis for the observation that relapse of IBD often follows infection.

\section{Authors' affiliations}

S L-F Pender*, V Chance*, M Buckley, T T MacDonald, Division of Infection, Inflammation, and Repair, University of Southampton School of Medicine, Southampton, UK

C V Whiting, Division of Veterinary Pathology, Infection, and Immunity, Department of Clinical Veterinary Science, University of Bristol, Langford, Avon, UK

R Pettipher, M Edwards, Oxagen Ltd, Milton Science Park, Oxfordshire, UK

*Both of these authors provided data crucial to this publication and so joint first authorship is acknowledged.

Conflict of interest: None declared.

\section{REFERENCES}

1 Schreiber S, Nikolaus S, Hampe J, et al. Tumour necrosis factor alpha and interleukin 1 beta in relapse of Crohn's disease. Lancet 1999;353:459-61.

2 Franklin WA, McDonald GB, Stein $\mathrm{HO}$, et al. Immunohistologic demonstration of abnormal colonic crypt cell kinetics in ulcerative colitis. Hum Pathol 1985; 16:1129-32.

3 Delpre G, Avidor I, Steinherz R, et al. Ultrastructural abnormalities in endoscopically and histologically normal and involved colon in ulcerative colitis. Am J Gastroenterol 1989;84:1038-46.

4 Fell JM, Paintin M, Arnaud-Battandier F, et al. Mucosal healing and a fall in mucosal pro-inflammatory cytokine mRNA induced by a specific oral polymeric diet in paediatric Crohn's disease. Aliment Pharmacol Ther 2000; 14:281-9.

5 Modigliani R, Mary JY, Simon JF, et al. Clinical, biological, and endoscopic picture of attacks of Crohn's disease. Evolution on prednisolone. Groupe d'Etude Therapeutique des Affections Inflammatoires Digestives. Gastroenterology 1990;98:811-18.

6 Gebhard RL, Greenberg HB, Singh N, et al. Acute viral enteritis and exacerbations of inflammatory bowel disease. Gastroenterology 1982:83:1207-9.

7 Stallmach A, Carstens $O$. Role of infections in the manifestation or reactivation of inflammatory bowel diseases. Inflamm Bowel Dis 2002;8:213-18.

8 Kangro HO, Chong SK, Hardiman A, et al. A prospective study of viral and mycoplasma infections in chronic inflammatory bowel disease. Gastroenterology 1990;98:549-53.

9 Sheeran P, Jafri H, CarubelliC, et al. Elevated cytokine concentrations in the nasopharyngeal and tracheal secretions of children with respiratory syncytial virus disease. Pediatr Infect Dis J 1999;18:115-22.

10 Bonville CA, Rosenberg HF, Domachowske JB. Macrophage inflammatory protein-lalpha and RANTES are present in nasal secretions during ongoing upper respiratory tract infection. Pediatr Allergy Immunol 1999;10:39-44.

11 Garofalo RP, Patti J, Hintz KA, et al. Macrophage inflammatory proteinlalpha (not T helper type 2 cytokines) is associated with severe forms of respiratory syncytial virus bronchiolitis. J Infect Dis 2001;184:393-9.

12 Miller AL, Bowlin TL, Lukacs NW. Respiratory syncytial virus-induced chemokine production: linking viral replication to chemokine production in vitro and in vivo. J Infect Dis 2004;189:1419-30.

13 Mellow TE, Murphy PC, Carson JL, et al. The effect of respiratory synctial virus on chemokine release by differentiated airway epithelium. Exp Lung Res 2004;30:43-57.

14 McColl SR, Hachicha M, Levasseur S, et al. Uncoupling of early signal transduction events from effector function in human peripheral blood neutrophils in response to recombinant macrophage inflammatory proteins- 1 alpha and -1 beta. J Immunol 1993;150:4550-60. 
15 Loetscher P, Seitz M, Clark-Lewis I, et al. Activation of NK cells by CC chemokines. Chemotaxis, $\mathrm{Ca} 2+$ mobilization, and enzyme release. J Immunol 1996; 156:322-7

16 Dorner BG, Scheffold A, Rolph MS, et al. MIP-1 alpha, MIP-1 beta, RANTES, and ATAC/lymphotactin function together with IFN-gamma as type 1 cytokines. Proc Natl Acad Sci U S A 2002;99:6181-6.

17 Staudinger R, Phogat SK, Xiao X, et al. Evidence for CD4-enchanced signaling through the chemokine receptor CCR5. J Biol Chem 2003;278: 10389-92.

18 Menten P, Wuyts A, Van Damme J. Macrophage inflammatory protein-1. Cytokine Growth Factor Rev 2002;13:455-81.

19 Schall TJ, Bacon K, Camp RD, et al. Human macrophage inflammatory protein alpha (MIP-1 alpha) and MIP-1 beta chemokines attract distinct populations of lymphocytes. J Exp Med 1993;177:1821-6.

20 Uguccioni M, D'Apuzzo M, Loetscher $M$, et al. Actions of the chemotactic cytokines MCP-1, MCP-2, MCP-3, RANTES, MIP-1 alpha and MIP-1 beta on human monocytes. Eur J Immunol 1995;25:64-8.

21 Simmons CP, Goncalves NS, Ghaem-Maghami M, et al. Impaired resistance and enhanced pathology during infection with a noninvasive, attachingeffacing enteric bacterial pathogen, Citrobacter rodentium, in mice lacking IL12 or IFN-gamma. J Immunol 2002;168:1804-12.

22 Li CKF, Pender SLF, Chance V, et al. Impaired immunity to intestinal bacterial infection in stromelysin-1 (matrix metalloproteinase-3)-deficient mice. $\mathrm{J}$ Immunol 2004:173:5171-9.

23 Goncalves NS, Hale C, Dougan G, et al. Binding of intimin from enteropathogenic Escherichia coli to lymphocytes and its functiona consequences. Infect Immun 2003;71:2960-5.

24 Verderio E, Gaudry C, Gross S, et al. Regulation of cell surface tissue transglutaminase: effects on matrix storage of latent transforming growth factor-beta binding protein-1. J Histochem Cytochem 1999;47:1417-32.

25 Karpus WJ, Lukacs NW, Kennedy KJ, et al. Differential CC chemokineinduced enhancement of T helper cell cytokine production. J Immunol 1997:158:4129-36

26 Nanki T, Nagasaka K, Hayashida K, et al. Chemokines regulate IL-6 and IL-8 production by fibroblast-like synoviocytes from patients with rheumatoid arthritis. J Immunol 2001;167:5381-5.

27 Knapp S, Thalhammer F, Locker GJ, et al. Prognostic value of MIP-1 alpha, TGF-beta 2, sELAM-1, and sVCAM-1 in patients with gram-positive sepsis. Clin Immunol Immunopathol 1998;87:139-44.

28 Sullivan SE, Staba SL, Gersting JA, et al. Circulating concentrations of chemokines in cord blood, neonates, and adults. Pediatr Res 2002;51:653-7.

29 Proulx F, Toledano B, Phan V, et al. Circulating granulocyte colony-stimulating factor, C-X-C, and C-C chemokines in children with Escherichia coli O157:H7 associated hemolytic uremic syndrome. Pediatr Res 2002;52:928-34.

30 Stoiser B, Knapp S, Thalhammer F, et al. Time course of immunological markers in patients with the systemic inflammatory response syndrome: evaluation of sCD14, sVCAM-1, sELAM-1, MIP-1 alpha and TGF-beta 2 Eur J Clin Invest 1998;28:672-8.

31 Lord BI, Dexter TM, Clements JM, et al. Macrophage-inflammatory protein protects multipotent hematopoietic cells from the cytotoxic effects of hydroxyurea in vivo. Blood 1992:79.2605-9.

32 Marshall E, Howell AH, Powles R, et al. Clinical effects of human macrophage inflammatory protein-1 alpha MIP-1 alpha (LD78) administration to humans: a phase I study in cancer patients and normal healthy volunteers with the genetically engineered variant, BB-10010. Eur J Cancer 1998;34:1023-9.

33 Lord BI, Woolford LB, Wood LM, et al. Mobilization of early hematopoietic progenitor cells with BB-10010: a genetically engineered variant of human macrophage inflammatory protein-1 alpha. Blood 1995:85:3412-15.

34 Zhang $\mathrm{Y}$, Yoneyama $\mathrm{H}$, Wang $\mathrm{Y}$, et al. Mobilization of dendritic cell precursors into the circulation by administration of MIP-lalpha in mice. J Natl Cancer Inst 2004;96:201-9.

35 Lord BI, Marshall E, Woolford LB, et al. BB-10010/MIP-1 alpha in vivo maintains haemopoietic recovery following repeated cycles of sublethal irradiation. Br J Cancer 1996;74:1017-22.

36 Scheerens $H$, Hessel E, Waal-Malefyt R, et al. Characterization of chemokines and chemokine receptors in two murine models of inflammatory bowel disease: IL-10-/ - mice and Rag-2-/- mice reconstituted with CD4+CD45RBhigh T cells. Eur J Immunol 2001;31:1465-74.

37 Ajuebor MN, Hogaboam CM, Kunkel SL, et al. The chemokine RANTES is a crucial mediator of the progression from acute to chronic colitis in the rat. $\mathrm{J}$ Immunol 2001:166:552-8.

38 Andres PG, Beck PL, Mizoguchi E, et al. Mice with a selective deletion of the CC chemokine receptors 5 or 2 are protected from dextran sodium sulfatemediated colitis: lack of CC chemokine receptor 5 expression results in a NK1.1+ lymphocyte-associated Th2-type immune response in the intestine. J Immunol 2000;164:6303-12.

39 Lee C, Liu QH, Tomkowicz B, et al. Macrophage activation through. J Leukoc Biol 2003;74:676-82.

40 Williams SL, Addison IE, Mollapour E, et al. The effects of human macrophage inflammatory protein-1 alpha and its genetically modified variant, BB10010, on phagocyte function. Cytokines Cell Mol Ther 1997:3:41-50.

41 Taub DD, Turcovski-Corrales SM, Key ML, et al. Chemokines and T lymphocyte activation: I. Beta chemokines costimulate human $T$ lymphocyte activation in vitro. J Immunol 1996;156:2095-103.

42 Lillard JW Jr, Singh UP, Boyaka PN, et al. MIP-1 alpha and MIP-1 beta differentially mediate mucosal and systemic adaptive immunity. Blood 2003;101:807-14.

43 Wong M, Fish EN. RANTES and MIP-1 alpha activate stats in T cells. J Biol Chem 1998:273:309-14

44 Lighvani AA, Frucht DM, Jankovic D, et al. T-bet is rapidly induced by interferon-gamma in lymphoid and myeloid cells. Proc Natl Acad Sci U S A 2001;98:15137-42.

45 Monteleone G, Pender SL, Wathen NC, et al. Interferon-alpha drives T cellmediated immunopathology in the intestine. Eur J Immunol $2001 \cdot 31 \cdot 2247-55$

46 Ganju RK, Brubaker SA, Chernock RD, et al. Beta-chemokine receptor CCR5 signals through SHP1, SHP2, and Syk. J Biol Chem 2000;275:17263-8.

47 Vainer B, Nielsen OH, Horn T. Expression of E-selectin, sialyl Lewis X, and macrophage inflammatory protein-lalpha by colonic epithelial cells in ulcerative colitis. Dig Dis Sci 1998;43:596-608.

48 Banks C, Bateman A, Payne R, et al. Chemokine expression in IBD. Mucosal chemokine expression is unselectively increased in both ulcerative colitis and Crohn's disease. J Pathol 2003;199:28-35.

49 Ajuebor MN, Kunkel SL, Hogaboam CM. The role of CCL3/macrophage inflammatory protein-lalpha in experimental colitis. Eur J Pharmacol 2004;497:343-9.

\section{bmjupdates+}

bmjupdates+ is a unique and free alerting service, designed to keep you up to date with the medical literature that is truly important to your practice.

bmjupdates+ will alert you to important new research and will provide you with the best new evidence concerning important advances in health care, tailored to your medical interests and time demands.

Where does the information come from?

bmiupdates+ applies an expert critical appraisal filter to over 100 top medical journals A panel of over 2000 physicians find the few 'must read' studies for each area of clinical interest

Sign up to receive your tailored email alerts, searching access and more...

www.bmjupdates.com 